\section{Identification of submarine groundwater discharge using thermal infrared observations in the Arabian Ocean near Okha coast, Gujarat, India}

\author{
R. P. Singh*, Shard Chander, \\ Ratheesh Ramakrishnan, Ashwin Gujrati, \\ Rohit Pradhan, Chirag Wadhwa,

\section{A. S. Rajawat and Raj Kumar} \\ Space Applications Centre, Indian Space Research Organisation, \\ Ahmedabad 380 015, India
}

In this study we identify a region of submarine groundwater discharge (SGD) near Okha coast, Gujarat, India using thermal infrared remote sensing technique. Observations of brightness temperature (BT) in the thermal infrared spectral region $(10.6-11.19 \mu \mathrm{m})$ from Landsat-8 satellite in the coastal region showed unique localized cooling in the Arabian Sea during winter. We observed lowering of $B T$ in the range $0.6^{\circ}-$ $2.3^{\circ} \mathrm{C}$ in the coastal region associated with SGD in comparison to sea surface temperature of the ocean during low-tide conditions. Consistent geographical pattern of thermal contrast was observed near the same location (lat. $22^{\circ} 26^{\prime} 54.43^{\prime \prime} \mathrm{N}$, long. $69^{\circ} 00^{\prime} 41.67^{\prime \prime} \mathrm{E}$ ) when multi date (11 datasets) thermal data were analysed between 2015 and 2019 in winter. Generally, low-tide conditions show more cooling of ocean surface at the SGD site compared to high-tide conditions, which indicates the process of SGD. Satellite-based assessment was further validated using field- and ship-based measurements.

Keywords: Brightness temperature, coastal region, submarine groundwater discharge, thermal infrared remote sensing.

DETECTION of submarine groundwater discharge (SGD) region, and modelling the quantity of annual flux and its associated nutrient load are important for understanding the hydro-geological processes of coastal regions ${ }^{1}$. SGD is a hydrological process of coastal areas in which submarine inflow of fresh and brackish groundwater takes place from land to sea ${ }^{2,3}$. SGD mainly occurs due to freshwater release from land to sea as base flow as well as overflow through the unconfined aquifer medium ${ }^{4}$. SGD occurs in the form of both point source plume discharge (submarine springs) and non-point source diffuse discharge (seepage), and its strength varies spatially as well as with changes in tidal conditions ${ }^{3,5}$. Detection of SGD sites in the coastal ocean is a challenging task as information on the source of potential offshore groundwater is important in hydrological management under condi-

\footnotetext{
*For correspondence. (e-mail: rpsingh@sac.isro.gov.in)
}

tions of freshwater scarcity. Many SGD sites are known worldwide $^{6-8}$, but limited information is available on the nearshore groundwater discharges in the Indian coastline. Ground-based studies carried out in the country provide the background knowledge of nearshore SGD and estuarine influx over selected sites in the Indian coast ${ }^{4,9,10}$. Global sites are mostly concentrated along the east coast of USA, Japan, north of the Italian coast, including sites in Australia, South Pacific Africa, Hawaii, California, Alaska and Canada. The eastern Mediterranean coast has many SGD sites and has been intensively studied ${ }^{6}$. Change in temperature of seawater due to SGD is a known process in many of these sites. Remote sensingbased detections are few due to limitation in spatial resolution and detectability of thermal instruments.

India has a long coastline bordering Bay of Bengal in the east and Arabian Sea in the west. Based on limited isotopic studies ${ }^{9,10}$ and electrical resistivity imaging ${ }^{4,11,12}$, the Indian subcontinent is considered a potential source of SGD as it is associated with high rainfall condition with major river flows into the oceans. Moore ${ }^{13}$ inferred large source of groundwater through observations of high flux of radium and barium from the mouth of the Ganges-Brahmaputra river system during low river discharge. The Ministry of Earth Science, Government of India is implementing a national network project on SGD through the National Centre for Earth Science Studies (www.ncesss.gov.in) to recognize potential zones where groundwater is flowing to the sea through coastal aquifers $^{14,15}$. Identification of coastal zones where SGD activities take place in large tracks of the coast is challenging without prior knowledge and local wisdom. Airborne and satellite-based thermal infrared remote sensing technique has the potential to provide valuable information on SGD over large spatial scales, which is helpful in reducing the extensive field efforts ${ }^{1,16}$. Density of water is known to increase with salinity and decrease with temperature ${ }^{17}$. Groundwater being less dense than seawater results in buoyant water plume and creates thermal contrast in the inflowing SGD and ocean surface $^{1}$. Initial physical formulations of seawater-groundwater interaction were made by Herzberg ${ }^{18}$, as cited by Bear et al. ${ }^{19}$. Apart from several reasons reported in the literature ${ }^{7,20}$ related with the SGD process (buoyancy and pressure gradient, deep pore water upwelling, offshore submarine springs, ripple through sea floor currents, etc.), density difference of freshwater $\left(1000 \mathrm{~kg} / \mathrm{m}^{3}\right)$ and saline ocean $\left(1025 \mathrm{~kg} / \mathrm{m}^{3}\right)$ helps to seep and discharge groundwater near the sea surface when sufficient pressure gradient exists. Seasonal behaviour of ocean surface being more stable compared to land surface temperature and inland water helps in the discrimination of SGD sites near the coastal region. Generally, it is found that locations in the ocean associated with SGD are cooler than other ocean regions during winter. Often, the size of SGD sites is smaller and associated temperature differences from 
Table 1. Dates of Landsat-8 data used in analysis, associated tidal conditions during image acquisition cumulative rainfall in the monsoon season, area influenced by submarine groundwater discharge (SGD) during low-tide conditions and tidal condition assessed at $1130 \mathrm{~h}$ using WxTide software

\begin{tabular}{|c|c|c|c|c|}
\hline Date & Path/row & Tide height $(\mathrm{m})$ & $\begin{array}{l}\text { Precipitation }{ }^{\#} \text { in monsoon } \\
\text { (JJAS) }(\mathrm{mm})\end{array}$ & $\begin{array}{c}\text { Area influenced by cooling due } \\
\text { to SGD (ha) }\end{array}$ \\
\hline \multicolumn{5}{|c|}{ Winter season after monsoon 2015} \\
\hline 5 March 2016 & $151 / 45$ & 2.24 & 323.9 & - \\
\hline \multicolumn{5}{|c|}{ Winter season after monsoon 2016} \\
\hline 2 December 2016 & $151 / 44$ & 2.08 & \multirow{4}{*}{350.2} & - \\
\hline 3 January 2017 & $151 / 44$ & 1.20 & & 29.88 \\
\hline 19 January 2017 & $151 / 45$ & 0.96 & & - \\
\hline 20 February 2017 & $151 / 44$ & 1.34 & & - \\
\hline \multicolumn{5}{|c|}{ Winter season after monsoon 2017} \\
\hline 3 November 2017 & $151 / 44$ & 3.50 & \multirow{3}{*}{345.2} & - \\
\hline 6 January 2018 & $151 / 44$ & 1.01 & & 50.40 \\
\hline 22 January 2018 & $151 / 44$ & 1.16 & & 26.28 \\
\hline \multicolumn{5}{|c|}{ Winter season after monsoon 2019} \\
\hline
\end{tabular}

"India Meteorological Department cumulative rainfall data of the June to September period.

background seawater are less than $1^{\circ} \mathrm{C}$, which pose a challenge in detecting regions of SGD. Few studies on thermal remote sensing of SGD have been carried out globally, but no such studies have been reported on nearshore groundwater discharges in the Indian coastline. We report one such unique SGD site near Okha coast, India, by observing systematic patterns of cooling using thermal infrared remote sensing technique.

The objective of the study was to identify the novel SGD region using satellite-based thermal remote sensing. The study was carried out in the Arabian Sea near the western coast of Okha, located at lat. $22^{\circ} 28^{\prime} \mathrm{N}$ and long. $69^{\circ} 4^{\prime} \mathrm{E}$. Okha is a coastal town in Dwarka district, Gujarat. It is surrounded by sea on three sides, but this study was mainly concentrated towards the western sandy beach on the Arabian Sea. Okha has a semi-arid to arid climate. Maximum temperature prevails in May-June in summer and minimum during winter months of December-January. July is the wettest month. October and November are the post-monsoon transition period from rainy to cold season.

The scientific basis of choosing this region was mainly due to geo-hydrological considerations which are favourable for Okha region due to availability of sufficient rainfall (Table 1), limestone rocks ${ }^{21}$ and less drainage density $^{22}$. Geomorphologically the study region is associated with flat coastal plains with exposure of coral bioherm and shell limestone (bioclastic) of the Chaya formation (Pleistocene) ${ }^{21}$. Underground water flows along the pores-spaces, cracks, fissures, shears, faults and cavities in the rocks. Porosity and permeability of the rocks dictates the availability of groundwater in the region apart from precipitation and slope/drainage characteristics. The region is poorly drained and so water percolates to its maximum depth through cracks, crevices and solution cavities ${ }^{23,24}$ compared to the Deccan trap (southern part of Saurashtra) which has less percolation due to high drainage density and associated high run-off. Groundwater occurs at shallow depths near the coast in the Miliolite limestone, Dwarka and Gaj limestone. According to the classification of Das and Prakash ${ }^{24}$, Mithapur and Okha regions fall in the high groundwater discharge rate zone (5000-7000 lpm). Overexploitation of groundwater also results in salinity ingression in the coastal regions.

Optical and thermal infrared band data of Landsat- 8 satellite were used for the analysis. The Landsat series is currently the only operational satellite system which has thermal sensing at high spatial resolution $(100 \mathrm{~m})$. All the band data were available at resampled $30 \mathrm{~m}$ spatial resolution. Eleven cloud-free Landsat-8 scenes spanning between 16 December 2015 and 9 November 2019 were analysed during winter to detect and characterize SGD. Table 1 shows the dates of satellite data acquisition, precipitation in monsoon, area of influence by cooling due to SGD and tidal conditions during the satellite data overpass. Field- and ship-based campaign was carried out on 22 January 2018 synchronous to satellite pass for validation. A handheld thermal imaging camera as well conductivity temperature and depth (CTD) instrument were used during field measurement. Figure 1 shows the optical and thermal image of the study area taken from Landsat- 8 satellite.

All the satellite data (Table 1) were acquired from Earth Explorer web portal and processed to compute top of atmospheric (TOA) radiance using the given scaling coefficients (multiplicative as well as additive factors). Brightness temperature (BT) was calculated by inverting the TOA radiance using Planck's law. BT values of band $10(10.6-11.19 \mu \mathrm{m})$ of Landsat-8 data were used in the 

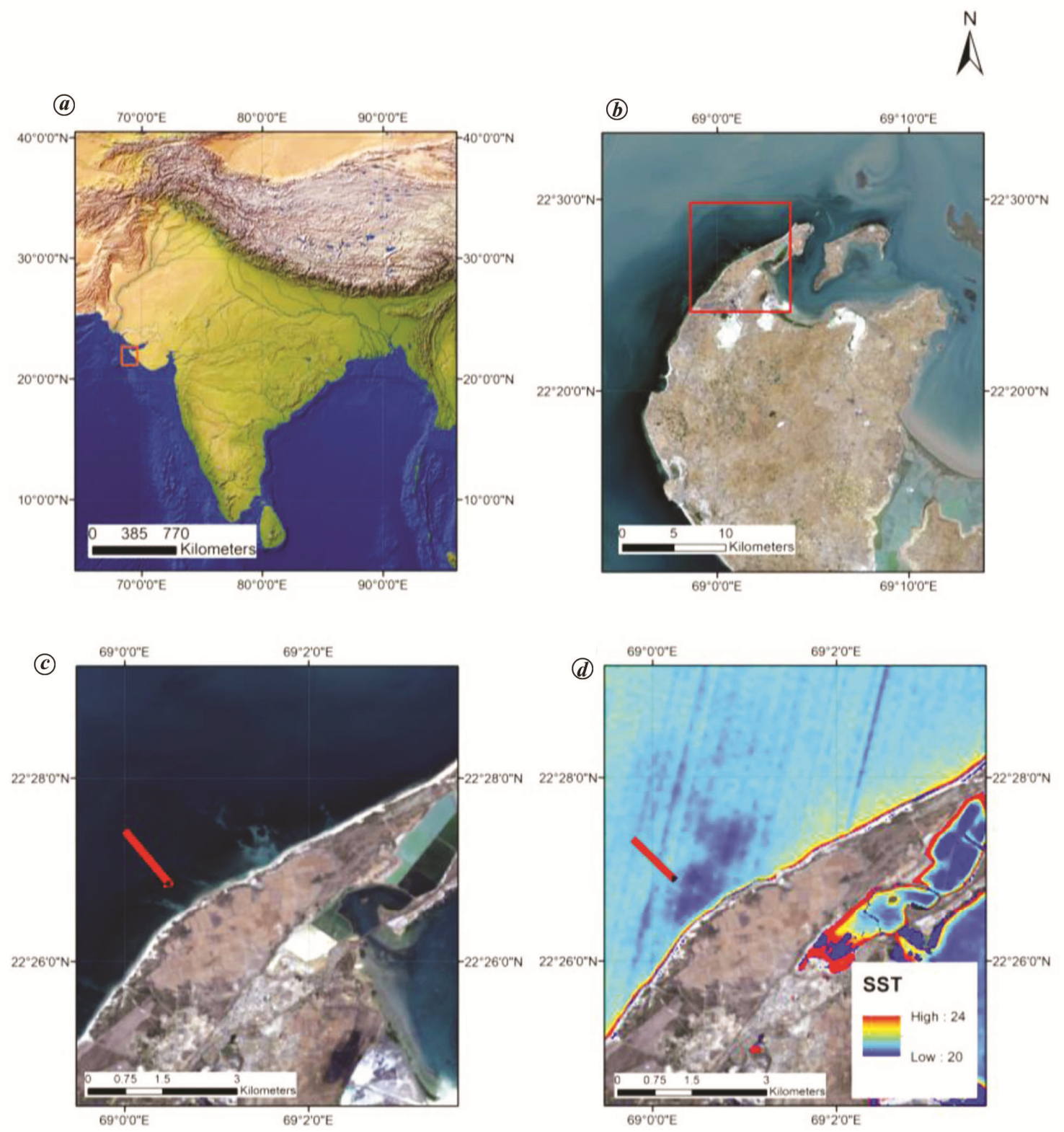

Figure 1. Study area showing (a) overview of India, (b) natural colour composite (NCC) of the region near Okha, Gujarat, $(\boldsymbol{c})$ zoomed NCC of detected submarine groundwater discharge (SGD) site (arrow) along with (d) sea surface temperature estimated from satellite thermal data showing SGD-induced cooling of the sea near western Okha coast on 22 January 2018.

analysis. Spatial BT variations were studied in the coastal region as well as the ocean region along with variations in reflectance in the visible bands. Unique spatial pattern of lowering of temperature in the background of the ocean was searched as the probable SGD site. Care was taken to observe this SGD pattern in multiyear data for confirmation of the systematic process. Regions which showed random relative cooling or heating in different satellite passes were not considered for analysis. Temporal BT signatures of ocean, land, inland waterbody and SGD site were studied to understand the influence of temporal inland temperature on SGD. Difference between BT in February (less SGD flow) and in December (more
SGD flow) was analysed to delineate the SGD site with more contrast. Difference between ocean temperature and SGD location was also analysed with tide height at the time of satellite pass to study the effect of tide on surface cooling at the SGD location. Two representative regions of interest, viz. (i) covering the probable SGD region and (ii) ocean region far away from the coastal area were marked to assess the relative changes in surface temperature of SGD and the ocean. Mean difference between ocean temperature and SGD location was used as the threshold to compute the area of influence due to SGD (Table 1) for low-tide conditions. Area of influence due to SGD was computed by estimating the number of pixels 
showing cooler temperature than the mean difference between ocean temperature and SGD location.

Validation of relative cooling at SGD sites was carried by measuring systematic sea surface temperature in a transect from Okha coast to different locations in the ocean including the SGD site using CTD instrument (temperature accuracy: $0.1^{\circ} \mathrm{C}$ ) between 0900 and $1300 \mathrm{~h}$ on 22 January 2018. Another validation of SGD was carried out by field survey on 14 November 2019 at Arabsa Pir Dargah near Okha coast.

Satellite-based observations were analysed to detect SDG during winter months, mostly November to February. Choice of this period was due to the fact that: (i) it covers the post-monsoon period which is associated with high surface recharge and percolation, and availability of ground water; (ii) inland water and land surface are cooler during this period compared to summer, and (iii) availability of cloud-free images. Multiyear analysis of BT data near Okha coast showed peculiar thermal contrast in the same location, which was verified as the SGD site during field verification. The inland water and SGD showed similar temporal variation, but it was different from ocean BT (Figure 2). Inland water and SGD were relatively cooler in December and January in comparison to the ocean. Inland water and SGD temperatures were higher in February than ocean temperature due to land surface heating. Representative BT of land surface varied from $28^{\circ} \mathrm{C}$ to $30^{\circ} \mathrm{C}$ in this period whereas inland water, ocean and SGD site showed variation of BT between $20^{\circ} \mathrm{C}$ and $24^{\circ} \mathrm{C}$ (Figure 2). Optical images along with spatial variation of BT were analysed for 18 December 2016, 3 January 2017 and 20 February 2017. BT of the Arabian Sea (ranging from $20^{\circ} \mathrm{C}$ to $24^{\circ} \mathrm{C}$ during winter) showed localized pockets of low temperature $\left(20^{\circ}-23^{\circ} \mathrm{C}\right)$, similar to nearby inland surface water on 18 December

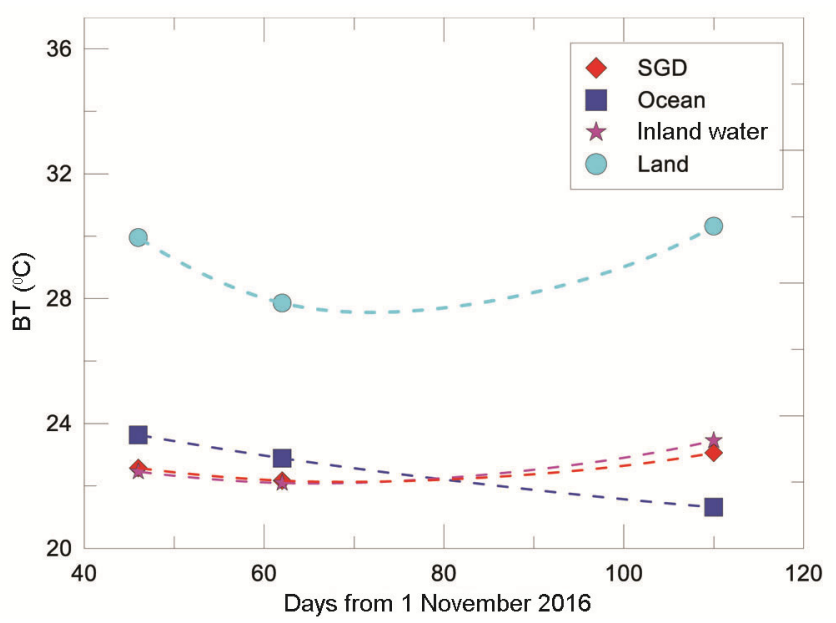

Figure 2. Brightness temperature (BT) variation near Okha coast during winter 2016-17. Four types of targets were studied, i.e. land surface, inland water, ocean and SGD location. The SGD site in the ocean showed characteristic temporal variation in BT, similar to inland water than ocean water.
2016 and 3 January 2017. Figure 3 shows the thermal anomaly (difference in BT between 20 February 2017 and 18 December 2016). The SGD location in this ocean showed positive values compared to the ocean, as SGD surface temperature was lower in December 2016 compared to February in 2017.

Further analysis was carried out to study the effect of surface cooling of the SGD site with reference to nearby ocean surface temperature using two representative regions of interest covering the probable SGD region and ocean region far away from the coastal area. To understand the consistency of SGD observations, more number of cloud-free Landsat- 8 scenes as given in the Table 1 were analysed. Most of the scenes showed relative cooling pattern at the same locations (SGD site) compared to ocean temperature during December and January. The SGD location is close to the coast and extends approximately $750 \mathrm{~m}$ in one direction (west of the coast). Cooling in the SGD was found as a systematic process. Transect analysis carried out on the 16 December 2015 data showed that ocean water temperature $3 \mathrm{~km}$ westward from the coast was stable $\left(\mathrm{SD}<0.5^{\circ} \mathrm{C}\right.$ ), whereas the SGD location showed lowering of temperature (signal up to $2{ }^{\circ} \mathrm{C}$ ) with respect to the ocean.

Figure 4 shows the difference between ocean temperature and of SGD location as a function of tide height at the time of satellite measurement. It can be seen that the differences in temperature are high (showing more cooling effect at the SGD site) at low-tide conditions compared to high-tide conditions where the differences are low showing less SGD flow. Overall inverse relationship $\left(r^{2}=0.42, F=5.06, P=0.059\right)$ was found between tide height and difference in temperature at the representative

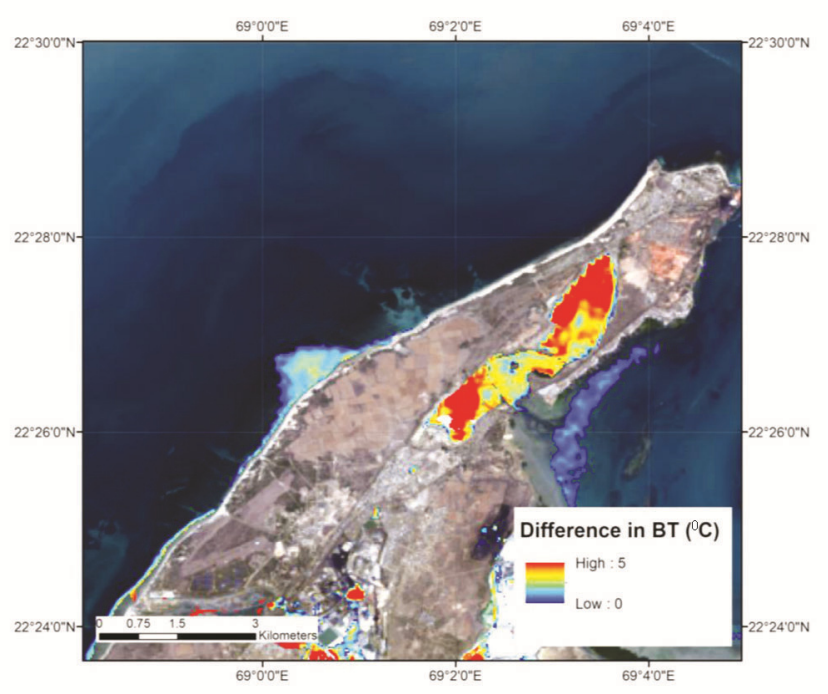

Figure 3. Thermal anomaly (difference in BT between 20 February 2017 and 18 December 2016) of water overlaid on the background optical image. The SGD location in the sea showed relative cooling in December 2016 similar to inland water bodies. The sea was relatively warm in December 2016 compared to February 2017. 
ocean and probable SGD location. The correlation (0.65) (significant at $90 \%$ confidence interval) between cooling of the SGD site and tide height for similar monsoon rainfall conditions indicates that cooling is associated with the SGD process. The SGD site showed contradictory behaviour to the above-mentioned hypothesis on 9 November 2019 , as substantial cooling $\left(1.37^{\circ} \mathrm{C}\right)$ was observed even at $3.05 \mathrm{~m}$ tide height condition. This could be due to high rainfall $(811 \mathrm{~mm})$ during monsoon in 2019 (Table 1) than normal rainfall $(250-324 \mathrm{~mm})$ in the preceding years. It shows the complex dependence of cooling due to $\mathrm{SGD}$, and hydro-geological and coastal processes.

Earlier researchers have also observed ocean surface cooling due to SGD at different sites across the world ${ }^{25}$. Tamborski et al. ${ }^{5}$ observed that locations associated with SGD were cooler than offshore ocean temperature ranging from $0.6^{\circ} \mathrm{C}$ to $2.1^{\circ} \mathrm{C}$ in selected sites near the north shore of Long island, NY, USA, using airborne thermal remote sensing. Similar ranges of cooling $\left(0.6^{\circ}-2.3^{\circ} \mathrm{C}\right)$ were observed in the present study. The locations of SGD are cooler due to mixing of groundwater, which is cooler in winter compared to the temperature of the vast ocean. In fact, SGD produces thermal anomaly. It can be cool in

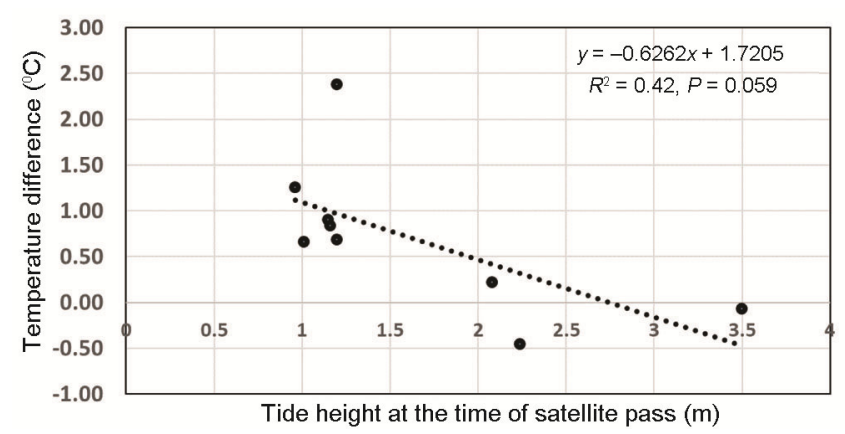

Figure 4. Effect of tide on surface cooling at the SGD location. Difference between ocean temperature and SGD location is plotted as a function of tide height at the time of satellite measurement.

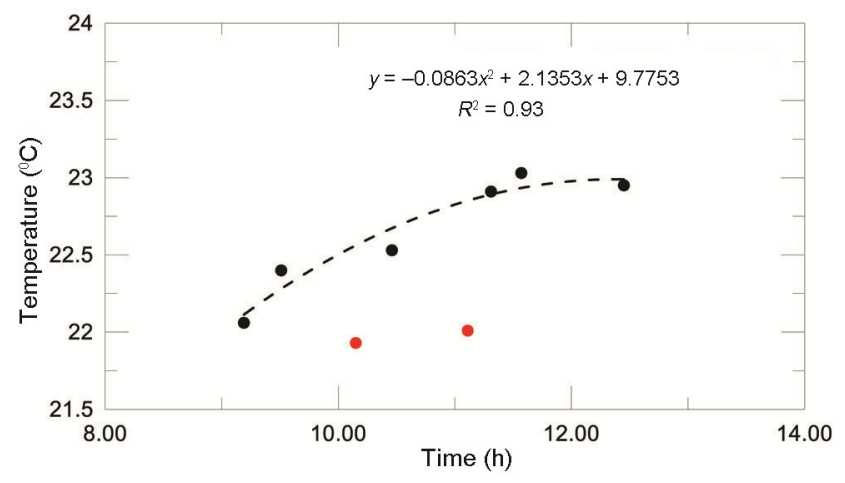

Figure 5. Diurnal variation in ocean surface temperature as measured at different locations near the Okha coast. Red dots show the lower surface temperature of the SGD site measured twice during a ship cruise on 22 January 2018, compared to temperature variation in other ocean locations (black dots). winter and warm in summer modulated by changing ground temperature. Satellite observations of 20 February 2016 showed warmer temperature anomaly $\left(1.57^{\circ} \mathrm{C}\right)$, with the SGD location temperature slightly higher than offshore ocean temperature. Tamborski et al. ${ }^{5}$ estimated the influence of thermal anomaly due to SGD in terms of spatial extent and found it to vary from 0.2 to 2.3 ha at different sites. Relatively large spatial dimension ( $>25$ ha) was observed in the present study (Table 1). Large spatial influence and consistent observations of SGD over the years in the present study suggest that there could be submerged fluvial channels in this region. The region is near (approx. $8 \mathrm{~km}$ ) the partially submerged Bet Dwarka island in the Gulf of Kutch region, Gujarat, which is an important archaeological site of Late Harappan period $^{26}$. More studies need to be carried out to support the hypothesis of existence of submerged fluvial channels near SGD site. The Gulf of Kutch region is also known for its submerged channels ${ }^{23}$. These channels were above the sea level during the Quaternary period when the streams were formed.

Cooling of the ocean surface can also take place due to mixing of surface flow of any river, or ocean eddies and turbulences. Adequate care should be taken to avoid other sources of cooling ocean surface to detect SGD. Availability of marine benthic vegetation is known to be associated with SGD due to nutrient flow ${ }^{2}$. A field campaign was carried out to validate cooling at the SGD location using CTD instrument on 22 January 2018. A ship cruise was carried out in the Arabian Sea near Okha coast for measurement of ocean temperature and salinity at different locations. Figure 5 shows the diurnal variation in ocean surface temperature measured at different locations near Okha coast, along with surface temperature observed at the SGD site. The SGD site showed characteristic lowering of surface temperature compared to the expected temperature of the ocean at the time of measurement. Expected temperature of the ocean was deduced from diurnal variations in temperature measured at different locations in the ocean during transect from Okha port to the SGD location and back to Okha port. To confirm cooling at the SGD location, we visited it at two different times while taking systematic temporal measurements in the ocean. Field survey on 14 November 2019 at Arabsa Pir Dargah (near Mithapur, Okha) revealed availability of fresh groundwater at very low depth $(\sim 1 \mathrm{~m})$ with salinity of $4.47 \mathrm{ppt}$ along the coast, and many sand boils and subsurface flows during low-tide conditions near the SGD site (Figure 6).

This study reports the identification of SGD near Okha coast, using satellite thermal infrared measurements. Localized surface cooling was observed at a fixed location in comparison to ocean surface temperature during winter due to SGD. Multiyear satellite-based measurements of relative cooling at the SGD site were validated with ship-based measurements and field survey. Exploration of 


\section{RESEARCH COMMUNICATIONS}
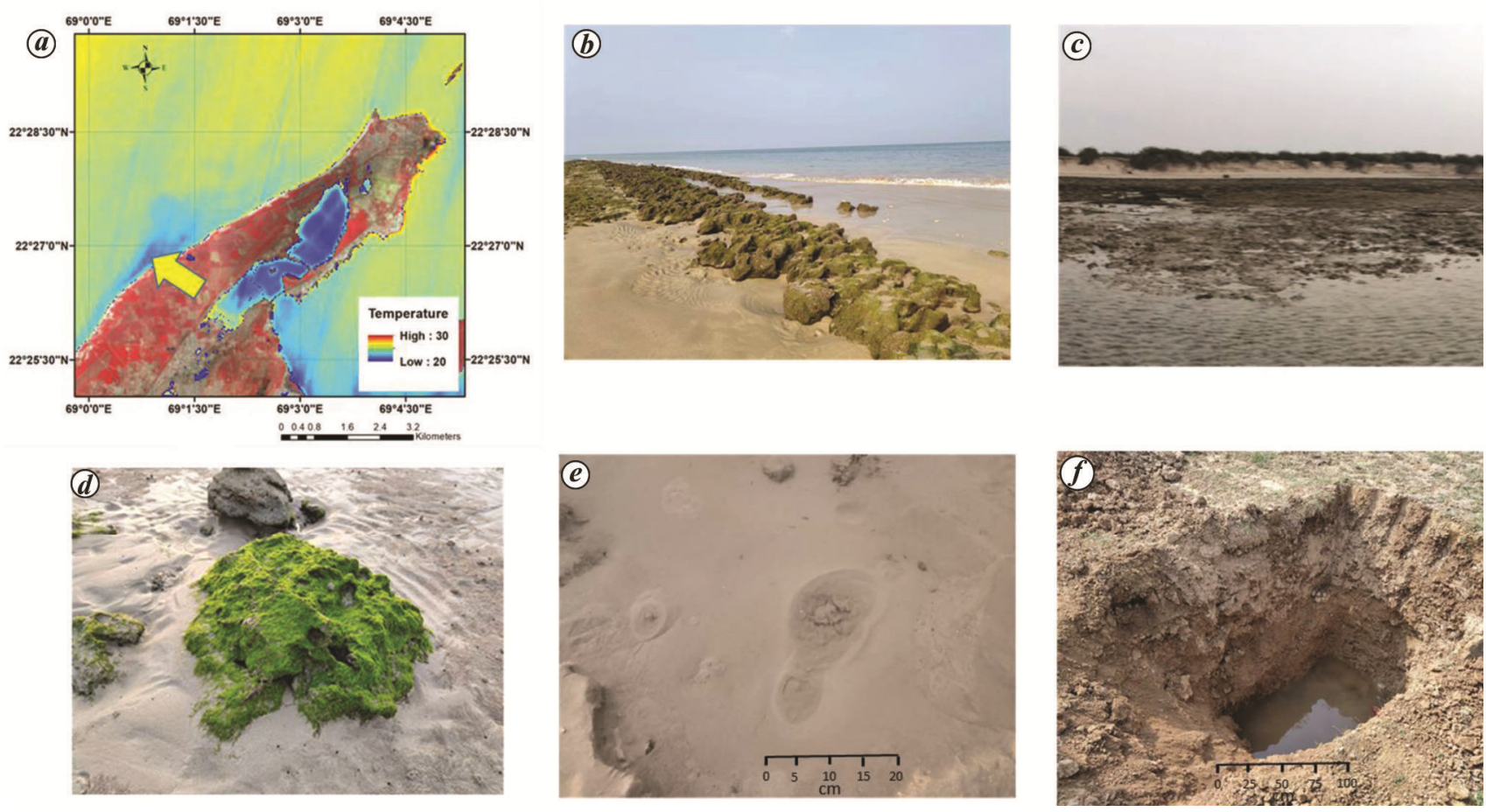

Figure 6. $\boldsymbol{a}$, Observation of SGD by satellite showing plume of relatively cooler temperature on the west coast on 9 November 2019 . BT of water is superimposed on false colour composite image of land. Arrow indicates regions where field verification was carried out on 14 November 2019. $\boldsymbol{b}$, Overview of the Arabian Sea near the SGD site during field verification. $\boldsymbol{c}$, Coastal region in the SGD site during low tide in which (d) benthic vegetation and $(\boldsymbol{e})$ sand boils were observed. $\boldsymbol{f}$, The SGD site was found associated with shallow groundwater near the sea coast.

SGD employing remote-sensing would help determine the amount of water going into the ocean using submarine pathways. This is essential to know the complete water balance of the region as well as to find a solution to the drinking water problem in the coastal region. SGD may be associated with change in water quality as well as salinity. Hyperspectral remote sensing data provide capability to quantify changes in water quality and should be explored for the study of SGD in future. L-band microwave radiometers have the capability to measure ocean salinity, but existing coarse-resolution satellite measurements (SMOS, SMAP, etc.) are not suitable to address the localized SGD sites, which are smaller in area. Further observations and verification experiments are needed to explore and quantify SGD at the proposed site in order to understand various biogeochemical processes in detail.

1. Xing, Q. et al., Detection of low salinity groundwater seeping into the Eastern Laizhou Bay (China) with the aid of Landsat thermal data. J. Coast. Res., 2016, 74, 149-156.

2. Lecher, A. L. and Mackey, K. R. M., Synthesizing the effects of submarine groundwater discharge on marine biota. Hydrology, 2018, 5(60); doi:10.3390/hydrology5040060.

3. Wang, S. et al., Submarine ground water discharge helps making nearshore water heterotrophic. Sci. Rep., 2018, 8, 11650; doi: 10.1038/s41598-018-30056-x

4. Suresh Babu, D. S., Anish, M., Vivekanandan, K. L., Ramanujam, N., Nathakiri Murugan, K. and Antony Ravindran, A., An account of submarine groundwater discharge from SW Indian coastal zone. J. Coast. Res., 2009, 25, 91-104.
5. Tamborski, J. J., Rogers, A. D., Bokuniewicz, H. J., Cochran, J. K and Young, C. R., Identification and quantification of diffuse fresh submarine groundwater discharge via airborne thermal infrared remote sensing. Remote Sensing Environ., 2015, 171, 202-217.

6. Taniguchi, M., Burnett, W. C., Cable, J. E. and Turner, J. V., Investigation of submarine groundwater discharge. Hydrol. Process, 2002, 16, 2115-2129.

7. Moore, W. S., The effect of submarine groundwater discharge on the ocean. Annu. Rev. Mar. Sci., 2010, 2, 59-88.

8. Peltonen, K., Direct groundwater flow to the Baltic Sea. Nordic Council of Ministers, Temanord, Copenhagen, 2002, p. 78.

9. Rahman, W. and Singh, S. K., Sr and ${ }^{87} \mathrm{Sr} /{ }^{86} \mathrm{SR}$ in estuaries of western India: impact of submarine ground water discharge. Geochim. Cosmochim. Acta, 2012, 85, 275-288.

10. Somayajulu, B. L. K., Sarma, V. V., Nair, S. and Gupta, S. K., Preliminary studies concerning SGD in India coastal region using ${ }^{228}$ radium and ${ }^{226}$ radium. In Proceedings of the INAC 2002: International Nuclear Atlantic Conference: 6 Brazilian National Meeting on Nuclear Applications, Brazil, 2002, p. 3080.

11. Ravindran, A. A. and Ramanujam, N., Detection of submarine groundwater discharge to coastal zone study using $2 \mathrm{~d}$ electrical resistivity imaging study at Mangapad, Tuticorin, India. Indian J. Geo-Mar. Sci., 2014, 43(2), 224-228.

12. Krishan, G., Rao, M. S., Kumar, C. P., Kumar, S. and Anand Rao, M. R., A study on Identification of submarine ground water discharge in northern east coast of India. Aquat. Procedia, 2015, 4, $3-10$.

13. Moore, W. S., High fluxes of radium and barium from the mouth of the Ganges-Brahmaputra River during low river discharge suggest large groundwater source. Earth Planet. Sci. Lett., 1997, 150, 141-150.

14. Suresh Babu, D. S., Padmalal, D. and Rao, P. N., Submarine groundwater discharge in Indian context. Curr. Sci., 2018, 115(12), 2197-2198. 
15. Selvam, S. et al., Quantification of submarine groundwater discharge (SGD) using radon, radium tracers and nutrient inputs in Punnakayal, south coast of India. Geosci. Front., 2020; https:// doi.org/10.1016/j.gsf.2020.06.012.

16. Mallast, U., Schwonke, F., Gloaguen, R., Geyer, S., Sauter, M. and Siebert, C., Airborne thermal data identifies groundwater discharge at the north-western coast of the Dead Sea. Remote Sensing, 2013, 5, 6361-6381.

17. Kundsen, M., Hydrological table, G.E.C., Gad. Copenhagen, 1901, p. 63.

18. Herzberg, A., Die wasserversorgung einiger Nordseebader. J. Gasbeleuchtung Wasseversorgung, 1901, 44, 815-819.

19. Bear, J., Cheng, H. D., Sorek, S., Ouuzar, D. and Herrera, I., Seawater Intrusion in Coastal Aquifers-Concepts, Methods and Practices, Kluwer Academic Publishers, Dordrecht, The Netherlands, 1999, p. 625.

20. Piekarek-Jankowska, H., Hydrochemical effects of submarine groundwater discharge to the Puck Bay (Southern Baltic Sea, Poland). Geogr. Pol., 1996, 67, 103-119.

21. Bhonde, U. and Desai, B. H., Discontinuity surfaces and even stratigraphy of Okha Shell Limestone Member: implications for Holocene sea level changes, western India. J. Earth Syst. Sci., 2011, 120, 723-734.

22. Mishra, D. C. et al., Major lineaments and gravity magnetic trends in Saurashtra, India. Curr. Sci., 2001, 80(8), 159-167.

23. Thorat, T. D., Geological studies on the coastline between Jamnagar and Okha Madhi in Saurashtra with special reference to geomorphology and neotectonism. $\mathrm{PhD}$ thesis, M S University Baroda, Vadodara, 1980.

24. Das, S. and Prakash, I., Assessment of groundwater hazards in coastal district of Gujarat, India. In Proceedings of International Conference Case Histories on Geotechnical Engineering, Arlington, VA, USA, 11-16 August 2008.

25. Taniguchi, M. et al., Submarine groundwater discharge updates on its measurements techniques, geophysical drivers, magnitude, and effects. Front. Environ. Sci., 2019, 7(141); doi:10.3389/fenvs. 2019.00141

26. Gaur, A. S. and Sundaresh, A unique Late Bronze Age copper fish-hook from Bet Dwarka Island, Gujarat, west coast of India: evidence on the advance fishing technology in ancient India. Curr. Sci., 2004, 86(4), 512-514.

ACKNOWLEDGEMENTS. We thank Shri D. K. Das, Director, Space Applications Centre (SAC), Ahmedabad for encouragement and guidance, and Dr Rashmi Sharma and Dr B. Kartikeyan (SAC) for useful suggestions which helped improve the manuscript. R.P.S. thanks Dr R. D. Deshpande (Physical Research Laboratory, Ahmedabad) and Dr D. S. Suresh Babu (National Centre for Earth Sciences Studies, Thiruvananthapuram) for fruitful discussions on SGD. The Earth Explorer web portal is acknowledged for providing Landsat-8 data.

Received 29 June 2020; revised accepted 7 September 2020

doi: $10.18520 / \mathrm{cs} / \mathrm{v} 119 / \mathrm{i} 9 / 1558-1564$

\section{Antibiotic resilience in Xanthomonas axonopodis pv. punicae causing bacterial blight of pomegranate}

\author{
Priyanka Krishna $^{1}$, M. K. Prasanna Kumar ${ }^{1, *}$, \\ Manjunatha Channappa ${ }^{2}$, Pramesh Devanna ${ }^{3}$, \\ Kartar Singh $^{4}$, Puneeth M. Eeregowda ${ }^{1}$, \\ H. B. Mahesh ${ }^{1}$, B. S. Chandrashekar ${ }^{1}$, \\ Venkatesh Babu ${ }^{5}$, Radhika U. Desai ${ }^{1}$ and \\ Sahana N. Banakar
}

${ }^{1}$ Department of Plant Pathology, University of Agricultural Sciences (UAS), Bengaluru 560 065, India

${ }^{2}$ ICAR-Indian Agricultural Research Institute, Regional Station, Wellington 643 231, India

${ }^{3}$ Agricultural Research Station, Gangavati, UAS, Raichur 584104 India

${ }^{4}$ ICAR-National Bureau of Plant Genetic Resources, Regional Station, Jodhpur 342 005, India

${ }^{5}$ Centre for Advanced Studies in Botany, University of Madras,

Guindy Campus, Chennai 600 005, India

Bacterial blight caused by Xanthomonas axonopodis pv. punicae (Xap) is one of the economically important diseases of pomegranate in India. Under field conditions, the disease is being managed using antibiotics and copper-based compounds but with limited success due to their poor bio-efficacy. The reduced efficacy of antibiotics and copper compounds against field populations of Xap might be due to the development of bactericide resistance through acquired genes. In the present study, ten bacterial blight-infected pomegranate samples were collected from different geographic locations of Karnataka, India, and causal agent Xap was isolated and identified through 16S rRNA sequencing. Streptomycin resistance genes such as $r p s \mathrm{~L}$, str $\mathrm{A}$, strB and copper resistance genes $\operatorname{cop} \mathrm{L}, \operatorname{cop} \mathrm{B}$ were detected using gene-specific primers in PCR. All ten isolates were positive for streptomycin resistance genes whereas copper resistance gene cop $B$ was absent in three isolates (Xap1, Xap4, Xap6) while copL was absent in Xap4 and Xap6 isolates. Further, in vitro experiments using different concentrations of streptomycin on culture media showed lowest growth inhibition up to $1500 \mu \mathrm{g} / \mathrm{ml}$ concentration, supporting the molecular evidence of antibiotic resistance. The present study provides preliminary information on the presence of antibiotic resistance genes in the field populations of Xap.

Keywords: Antibiotics, bacterial blight, copper compounds, disc diffusion, pomegranate, resistant genes.

IN recent years, bacterial blight or oily leaf spot disease has emerged as a major concern for pomegranate cultivation in all pomegranate-growing states of India. The disease is responsible for huge economic losses up to INR

*For correspondence. (e-mail: babu_prasanna@rediffmail.com) 